are available, as are expenses or the equivalent when appropriate.

Eden Naby, Co-Chairman

Afghanistan Council

The Library of Congress office in Cairo

Since 1962 the Library of Congress, through its Overseas Operations Division, has administered a group of programs to procure hardto-get publications in various countries around the world. Known officially as Special Foreign Acquisitions Programs but more commonly called PL-480 programs, they represent an unconventional approach to obtaining library materials in countries where the book trade is not well organized or geared for export. These programs are designed not only to bring material to the Library of Congress, but also to distribute publications to a group of American research libraries in support of their area studies interests.

The idea for these overseas activities arose in the 1950 s at a time of widespread dissatisfaction with the paucity of non-European research material in American library collections. A group of scholars suggested that foreign currencies, which had accrued to the U.S. government under Public Law 83-480 from the sale of agricultural commodities to developing countries, might be used to purchase books, journals and newspapers. The Special Foreign Acquisitions Program in Cairo was among the first to be established using local funds excess to the other needs of the U.S. government. The Cairo office is administered by an American field director and operates with a staff of local personnel.

Since the late $1960 \mathrm{~s}$, as excess foreign currencies diminished, programs in some countries have terminated. In other countries cooperative collecting efforts have been arranged under the Library's $\mathrm{Na}-$ tional Program for Acquisitions and Cataloging. NPAC offices acquire current materials of research value in order to disseminate cataloging data to libraries rapidly. This year excess Egyptian currency no longer being available to the Library of Congress, Cairo operations 
joined the list of NPAC offices. This means that libraries will continue to receive library materials from Egypt and other Arab countries, but that they will reimburse the Library of Congress for book and periodical receipts and contribute toward administrative cost. Each participating library has chosen to receive publications in subject fields and from geographic regions suited to its collecting interests. A library may elect to receive books from the following geographic areas: Egypt, Lebanon and Syria, Iraq, other eastern Arab countries, and North Africa. Subject groups are: Language and Literature, Islamic Studies, Modern Social Studies, Modern Law, and Science Technology.

Libraries contributing to the support of the NPAC office in Cairo are, in addition to the Library of Congress, the

American University in Cairo
University of Arizona
Boston Public Library
$U$ of California, Berkeley
$U$ of California, Los Angeles
University of Chicago
Columbia University
Georgetown University
Hartford Seminary Foundation
Harvard University
University of Illinois
Indiana University
University of Michigan

\author{
University of Minnesota \\ New York Public Library \\ New York University \\ Ohio State University \\ University of Pennsylvania \\ Portland State University \\ Princeton University \\ State University of NY, Binghamton \\ University of Texas \\ University of Utah \\ University of Virginia \\ University of Washington \\ Yale University
}

More information about the Library of Congress office in Cairo and its other overseas offices-Rio de Janeiro, Nairobi, Karachi, New Det hi and Jakarta - is available from: Library of Congress, Overseas Operations Division, Washington, D. C. 20540.

\author{
Michael W. Albin \\ Library of Congress
}

\title{
Middle East Outreach Council
}

At the MESA meeting in Salt Lake City, November 7-10, 1979, conference participants interested in outreach activities formed the Middle East Outreach Council (MEOC). The MEOC is independent of MESA, though it will meet in conjunction with it. Charlotte Wright, Outreach Coordinator at The University of Michigan Center for Near Eastern and North African Studies and editor of the Near East Outreach Newsletter, has agreed to chair the MEOC. Mobil Oil Corporation has contributed $\$ 2,500$ to underwrite expenses for the new organization.

The MEOC's purpose is to facilitate outreach activities on the Middle East through the exchange of information among outreach programs and personnel and the dissemination of information on the Middle East. The major vehicle for information exchange and dissemination is the Near East Outreach Newsletter. In addition, the MEOC plans to apply for funds to evaluate and disseminate materials for teachers. A committee composed of:

Barbro Ek, Outreach Coordinator, Harvard University Center for Middle Eastern Studies;

Jonathan Friedlander, Outreach Coordinator, UCLA Center for 